\title{
Kompostien kyky ehkäistä kasvien maalevintäisiä tauteja - kokemuksia Suomesta
}

\author{
Mauritz Vestberg ${ }^{1}$, Sanna Kukkonen ${ }^{1}$, Päivi Parikka ${ }^{2}$, Dan $\mathrm{Yu}^{3}$, Jukka Kurola ${ }^{3}$ Martin Romantschuk ${ }^{3}$ \\ ja Heikki Setälä ${ }^{3}$ \\ ${ }^{1}$ MTT, Kasvintuotannon tutkimus, Puutarha, Antinniementie 1, 41330 Vihtavuori \\ ${ }^{2}$ MTT, Kasvintuotannon tutkimus, 31600 Jokioinen \\ ${ }^{3}$ Helsingin Yliopisto, Ympäristöekologian laitos, Niemenkatu 73, 15140 Lahti
}

Komposti on maanparannusaine, jonka vaikutukset ovat moninaisia. Se vaikuttaa maaperän ja kasvualustan ravinnepitoisuuteen, rakenteeseen, huokoisuuteen, orgaaniseen ainekseen, vedenpidätyskykyyn ja voi parhaimmassa tapauksessa ehkäistä kasvien maalevintäisiä kasvitauteja. Kompostien kykyä ehkäistä maalevintäisiä kasvitauteja on Suomessa tutkittu vain vähän. Vuosina 2008 - 2010 toteutettiin Suomen Akatemian rahoittama Suomi - Intia hanke, jossa selvitetettiin mm. 1) esiintyykö suomalaisissa laitoskomposteissa estokykyä maalevintäisiä kasvitauteja vastaan, 2) löytyykö taudinestokykyä useampaa kasvitautia vastaan, 3) toistuuko taudinestokyky samoista raakaaineista tehdyissä eri kompostierissä ja 4) liittyykö kompostien taudinestokyky kompostien mikrobikoostumukseen. Tässä esityksessä keskitytään kohtiin 1-3.

Kokeissa oli mukana 21 kompostierää, jotka olivat peräisin kompostointilaitoksilta ympäri Suomea. Eri kompostien raaka-aineet vaihtelivat paljon; biojäte, puutarhajäte, metsäteollisuuden ja jätevesipuhdistamon liete sekä karjan-, hevosen- ja siipikarjan lanta. Komposteista 8 oli tuotettu aumoissa, 8 tunneleissa, 3 rummuissa ja 2 muulla tavoin. Kompostien taudinestokykyä tutkittiin ensin astiakokeissa mansikan tyvimätää ja kurkun lakastumistautia vastaan. Näissä kokeissa kompostit sekoitettiin 20 \%:na turvepitoiseen kasvualustaan, jota oli höyrytetty turpeen luontaisten mikrobien eliminoimiseksi. Sen jälkeen tutkittiin taudinestoa astiakokeessa, jossa oli luontaista peltomaata mukana. Lopuksi tutkittiin lupaavimmaksi todetun kompostin kykyä ehkäistä mansikan tyvimätää kenttäkokeessa.

Useiden kompostien osoitettiin astiakokeissa ehkäisevän tyvimätää mansikalla, lakastumistautia kurkulla tai molempia. Kompostierien vertailukoe osoitti, että tautisuppressiivisuus näyttäisi pääsääntöisesti toistuvan vuodesta toiseen jos kompostit oli tehty samoista raaka-aineista ja samalla menetelmällä. Suljetuissa kompostointireaktoreissa tuotetuista komposteista oli suurempi osuus kasvitauteja ehkäiseviä kuin aumoissa tuotetuista. Taudinestoilmiö heikkeni kun astiakokeissa oli peltomaata mukana. Kenttäkokeessa taudinestokykyisen kompostin levittämisestä ei voitu osoittaa olleen hyötyä mansikan tyvimädän torjunnassa.

Taudinestokyky on suomalaisissa laitoskomposteissa esiintyvä kompostien lisäarvo, jonka hyödyntäminen on mahdollista, mutta vasta lisätutkimusten jälkeen. Taudinestokyvyn olemassaolo on todettu, mutta ilmiön taustalla olevat mekanismit ovat vielä laajalti selvittämättä. Oletettavasti taudinestokyky liittyy tiettyihin kompostimikrobeihin ja näiden aineenvaihduntatuotteisiin, mutta vielä ei ole löytynyt sellaisia avainmikrobeja, jotka selittäisivät ilmiön. Sen jälkeen kun on saatu lisätietoja taudinestokyvyn taustalla olevista mekanismeista, on mahdollista hallita ilmiötä paremmin ja jopa räätälöidä komposteja, joilla on varma kyky estää kasvien maalevintäisiä kasvitauteja.

Asiasanat: komposti, kompostointilaitos, taudinestokyky, juuristotaudit, Phytophthora, Pythium 


\section{Johdanto}

Kompostin lisäyksen vaikutukset maaperään tai kasvualustaan ovat moninaisia. Komposti vaikuttaa ravinnepitoisuuteen ja voi pitkälle korvata väkilannoitteiden käytön. Sen lisäksi kompostilla on vaikutusta maan ja kasvualustan rakenteeseen, huokoisuuteen, orgaaniseen aineksen määrään sekä vedenpidätyskykyyn (Itävaara ym. 1997). Komposti voi parhaimmassa tapauksessa myös ehkäistä kasvien juuristotauteja.

Kompostien taudinestokyky mainittiin ensimmäistä kertaa yli kolme vuosikymmentä sitten kun Amerikassa oli havaittu, että havupuun kuoresta tehty komposti esti Fusarium oxysporum f.sp. chrysantemi -sienen aiheuttamaa krysanteemin juurilahoa (Hoitink \& Poole 1976). Sen jälkeen taudinestokykyä on todettu hyvin monenlaisia kasvitauteja vastaan, esim. Pythium, Phytophthora, Rhizoctonia, Sclerotinia, Sclerotium ja Verticillium (Hoitink ja Boehm 1999, Noble ja Coventry 2005, Raviv 2008, Raviv 2009). Myös patogeenisia bakteereita (Schönfeld ym. 2003) ja kasveja vioittavia ankeroisia (Oka \& Yermiyahu 2004) on pystytty torjumaan kompostia käyttämällä. Taudinestokykyä on löydetty hyvin erityyppisistä komposteista, joten on vaikeata päätellä mitkä kompostien raaka-aineet aiheuttavat taudinestokykyä ja mitkä eivät (Termorshuizen ym. 2006, Raviv 2009). Yhteistä useimmille tutkimuksille on että taudinestokykyä löytyy lähinnä vain kypsistä komposteista.

Taudinestomekanismien ymmärtäminen on tärkeää, jotta taudinestoilmiötä voitaisiin hyödyntää. Taudinstomekanismi voi olla joko spesifinen tai yleinen. Spesifisessä taudinestossa vaikutus liittyy kompostin johon tiettyyn mikro-organismiin. Hyvä esimerkki tällaisesta taudinestosta on puunkuoresta tehty komposti, jossa Trichoderma-sieni vastaa taudinestosta (Hoitink ja Boehm 1999). Yleinen taudinesto johtuu kompostissa olevien useiden mikrobiryhmien yhteisvaikutuksesta (Veeken ym. 2005). Mekanismeista mainittakoon (1) kompostimikrobien ja patogeenien kilpailu ravinteista (Chen ym. 1988), tilasta (Serra-Wittling ym. 1996) tai infektoitumiskohdista (Benhamou \& Garand 2001), 2) hyperparasitismi (Gorodecki \& Hadar 1990), 3) antibioosi (Raviv 2009), 4) kompostin aiheuttama patogeeni-itiöiden ennenaikainen itäminen (Yogev ym. 2006) ja 5) kasvin systeemisesti virittynyt kestävyys taudinaiheuttajia vastaan (Zhang ym. 1998). Yleisen taudinestoilmiön selittäjiksi on ehdotettu paitsi mikrobistot, myös kompostien kemialliset tai fysikaaliset ominaisuudet (Hoitink \& Boehm 1999; Raviv 2009).

Kompostin käyttöä maalevintäisten kasvitautien torjunnassa on Suomessa tutkittu vähän. Vuonna 2008 käynnistyi kansainvälinen Suomi - Intia projekti, jonka tavoitteena on tutkia ja hyödyntää kompostien taudinestokykyä. Suomessa hankkeeseen osallistuvat MTT, HY ja Eviran hyväksymiä kompostia tuottavia biolaitoksia. Tämä kirjoitus on yhteenveto Suomen osahankkeessa tehdyistä taudintorjuntakokeista.

\section{Aineisto ja menetelmät}

\section{Kompostit}

Kokeissa on ollut mukana 21 kompostierää, jotka olivat peräisin 13 kompostointilaitokselta ympäri Suomea. Kompostinäytteet kerättiin keväällä 2008 ja 2009. Kompostien raaka-aineet, tukiaineet ja kemialliset ominaisuudet vaihtelivat suuresti (katso Vestberg ym. 2010, 2011). Kompostien raakaaineina olivat biojäte, puutarhajäte, metsäteollisuuden ja yhdyskuntien jätevesiliete sekä karjan-, hevosen-, ja siipikarjan lanta. Kompostien tukiaineena oli käytetty turvetta, puupaloja, kuorta, olkea tai puun oksia. Myös kompostointitapa vaihteli. Kahdessa ensimmäisessä kokeessa oli mukana 8 aumakompostia, 8 tunnelikompostia, 3 rumpukompostia ja 2 kompostia, jotka oli tuotettu suljettujen reaktoreiden yhdistelmänä. Seuraaviin kokeisiin valittiin näistä parhaat saatujen tulosten perusteella. Komposteista määritettiin $\mathrm{pH}$, johtoluku, liukoiset ravinteet $(\mathrm{N}, \mathrm{P}, \mathrm{K})$, kokonaisravinteet $(\mathrm{C} \%$, N\%, kokonais-P, kokonais-K), kypsyysaste Rottegrad-testillä ja $\mathrm{NO}_{3}-\mathrm{N} / \mathrm{NH}_{4}$-suhteella. (katso Vestberg ym. 2010). 


\section{Taudinestokokeet}

Eri taudinestokokeissa tutkitut kompostit on esitetty Taulukossa 1. Vuonna 2008 kerätyistä 21 kompostierästä taudinestokykyä tutkittiin ensin mansikan tyvimätää (aiheuttaja Phytophthora cactorum) ja avomaankurkun lakastumistautia (aiheuttaja Pyhtium spp.) vastaan astiakokeissa. Kolmanteen astiakokeeseen valittiin lupaavimmat, taudinestokykyisiksi osoittautuneet 7 kompostia, yksi neutraali komposti ja yksi kurkun lakastumistautia lisäävä komposti. Näistä komposteista vertailtiin vuonna 2008 ja 2009 valmistuneita eriä. Astiakokeessa 4 tutkittiin kolmen taudinestokompostin vaikutuksia kurkun lakastumistautiin peltomaassa. Kenttäkokeessa tutkittiin lupaavimmaksi osoittautuneen lietekompostin vaikutuksia mansikan tyvimätään (Taulukko 1).

Astiakokeissa 1- 3 kompostia käytettiin 20\% höyrytettyyn turvepitoiseen kasvualustaan sekoitettuna. Turve-komposti -seoksia kalkittiin ja lannoitettiin eri tavalla riippuen kompostien ravinnepitoisuudesta ja pH:sta. Valmiin kasvualustan tavoitearvot olivat pH 6-6.5, johtoluku 4-8, N 250 mg, P 100 mg ja K 350 mg/l alustaa. Mansikkakoetta ei lannoitettu kokeen aikana, mutta kurkuille annettiin Puutarhan Täyslannosta kerran viikossa kastelun yhteydessä. Astiakokeessa 4, kompostit sekoitettiin joko luontaisen peltomaan (hkKht, MTT, Jokioinen) tai puutarhamaan (Kht, MTT, Piikkiö) kanssa. Piikkiössä suoritetussa kenttäkokeessa kompostia $\left(70 \mathrm{~m}^{3} / \mathrm{ha}\right)$ levitettiin mansikkarivin kohdalle sekä muokattiin maahan ennen mansikkaharjun tekoa ja taimien istutusta.

Kokeissa käytetyt kasvit olivat mikrolisätty mansikka 'Jonsok' sekä avomaankurkku 'Parmel'. Astiakokeen tyvimätäsaastutusta varten $P$. cactorum-sientä viljeltiin ensin 4 viikkoa agaralustalla (PDA). Saastutus tehtiin vuorokausi taimien istuttamisen jälkeen, jolloin saastutettaville taimille annosteltiin $100 \mathrm{ml}$ vettä, joka sisälsi keskimäärin 3200 sienen munapesäkkettä. Astiakokeita 2-4 varten Pyhtium-sientä viljeltiin PDA-alustalla n. viikon verran. Istuttamisen yhteydessä saastutettaville taimille annosteltiin $10 \mathrm{~g}$ agaralustaa, missä oli Pythium-sienirihmoja.

Taimien lehvästön kunto havainnoitiin kerran viikossa kaikissa kokeissa. Kurkun taimien pituus määritettiin ja lehtien lukumäärät laskettiin myös kerran viikossa. Mansikkakokeiden lopussa havainnoitiin juurakon ruskettuneisuus ja lehtien lakastuminen. Juuriston kunto määritettiin kurkkukokeissa. Molemmista tutkimuskasveista määritettiin myös versojen tuore- ja kuivapaino loppuvaiheessa.

\section{Tulokset}

\section{Taudinesto koko kompostiaineistossa}

Noin 30 - 40 \% tutkituista komposteista vähensi sekä tyvimädän ilmenemistä mansikalla että lakastumistaudin ilmenemistä avomaankurkulla. Kolme kompostia ehkäisi selvästi molempia kasvitauteja (kompostit 5, 14 ja 17). Tämän lisäksi mansikan tyvimätää ehkäisi enemmän tai vähemmän 6 ja kurkun lakastumistautia 11 kompostia. Kompostien väliset erot olivat selvempiä kurkku- kuin mansikkakokeissa. Myös kompostointitapa ja raaka-aineet vaikuttivat tuloksiin. Neljä viidestä parhaasta kompostista oli valmistettu suljetussa reaktorissa. Komposteihin käytetyt raaka-aineet vaihtelivat paljon, mutta taudinestokompostit oli valmistettu pääasiassa biojätteestä tai jätevesilietteestä. Lantakompostien joukosta ei juuri löytynyt taudinestokykyä. Siipikarjan lannasta valmistettu komposti jopa lisäsi lakastumistaudin ilmenemistä kurkulla. Raaka-aineiden vaikutuksesta taudinestoon jää kuitenkin epävarmaksi koska lantakompomposteja ei tehty suljetuissa reaktoreissa.

\section{Taudineston toistettavuus}

Jotta taudinestokyky olisi hyödynnettävissä, pitäisi ilmiön toistua vuodesta toiseen ainakin silloin, kun kompostit on valmistettu samoista raaka-aineista samaan aikaan vuodesta. Tätä asiaa tutkittiin yhdeksällä kompostilla. Taudinehkäisykyky näyttäisi pääsääntöisesti toistuvan (Kuva 1), vaikka kompostierien välillä esiintyi eroavaisuuksia koskien $\mathrm{pH}$ :ta, johtolukua ja ravinteiden määriä. Tässä vertailussa (kuten myös kokeessa 2) myös käsittelemätön turve vähensi tautia verrattuna verranteeseen (höyrytetty turve). 
Taulukko 1. Eri kokeissa käytetyt kompostit. Astiakokeiden 1 ja 2 perusteella tehtiin ensimmäinen kompostinvalinta. Kokeessa 3 tutkittiin taudinestokyvyn toistettavuutta eri kompostieristä. Astiakokeessa 3 tutkittiin taudinestoilmiön voimakkuutta peltomaassa.

\begin{tabular}{|c|c|c|c|c|c|c|}
\hline \multicolumn{2}{|c|}{ Kompostit } & \multirow{2}{*}{$\begin{array}{c}\text { Astiakoe } 1 \\
\text { Phytopthora } \\
\text { Mansikka }\end{array}$} & \multirow{2}{*}{$\begin{array}{c}\text { Astiakoe } 2 \\
\text { Pyhtium } \\
\text { Kurkku }\end{array}$} & \multirow{2}{*}{$\begin{array}{c}\text { Astiakoe } 3 \\
\text { Pyhtium } \\
\text { Kurkku }\end{array}$} & \multirow{2}{*}{$\begin{array}{c}\text { Astiakoe } 4 \\
\text { Pyhtium } \\
\text { Kurkku }\end{array}$} & \multirow{2}{*}{$\begin{array}{c}\text { Kenttäkoe } \\
\text { Phytopthora } \\
\text { Mansikka }\end{array}$} \\
\hline Nro & Raaka-aineet & & & & & \\
\hline 1 & SK-lanta & $\mathrm{x}$ & $\mathrm{x}$ & $\mathrm{x}$ & $\mathrm{x}$ & \\
\hline 2 & M-jäte/SK-lanta & $\mathrm{x}$ & $\mathrm{x}$ & & & \\
\hline 3 & Biojäte & $\mathrm{x}$ & $\mathrm{x}$ & $\mathrm{x}$ & $\mathrm{x}$ & \\
\hline 4 & M-liete & $\mathrm{x}$ & $\mathrm{x}$ & & & \\
\hline 5 & H-lanta/M-liete & $\mathrm{x}$ & $\mathrm{x}$ & $\mathrm{x}$ & & \\
\hline 6 & K-lanta/P-jäte & $\mathrm{x}$ & $\mathrm{x}$ & $\mathrm{x}$ & & \\
\hline 7 & Biojäte & $\mathrm{x}$ & $\mathrm{x}$ & $\mathrm{x}$ & & \\
\hline 8 & Biojäte/P-jäte & $\mathrm{x}$ & $\mathrm{x}$ & & & \\
\hline 9 & J-liete/P-jäte & $\mathrm{x}$ & $\mathrm{x}$ & & & \\
\hline 10 & H/K-lanta & $\mathrm{x}$ & $\mathrm{x}$ & & & \\
\hline 11 & J-liete & $\mathrm{x}$ & $\mathrm{x}$ & & & \\
\hline 12 & Kasvinjäte & $\mathrm{x}$ & $\mathrm{x}$ & & & \\
\hline 13 & Biojäte & $\mathrm{x}$ & $\mathrm{x}$ & $\mathrm{x}$ & & \\
\hline 14 & J-liete & $\mathrm{x}$ & $\mathrm{x}$ & $\mathrm{x}$ & $\mathrm{x}$ & $\mathrm{x}$ \\
\hline 15 & Biojäte & $\mathrm{x}$ & $\mathrm{x}$ & & & \\
\hline 16 & Biojäte & $\mathrm{x}$ & $\mathrm{x}$ & & & \\
\hline 17 & J-liete/Biojäte & $\mathrm{x}$ & $\mathrm{x}$ & $\mathrm{x}$ & & \\
\hline 18 & J-liete/Biojäte & $\mathrm{x}$ & $\mathrm{x}$ & & & \\
\hline 19 & J-liete/K-lanta & $\mathrm{x}$ & $\mathrm{x}$ & & & \\
\hline 20 & Biojäte & $\mathrm{x}$ & $\mathrm{x}$ & $\mathrm{x}$ & $\mathrm{x}$ & \\
\hline 21 & P-jäte & $\mathrm{x}$ & $\mathrm{x}$ & & & \\
\hline
\end{tabular}

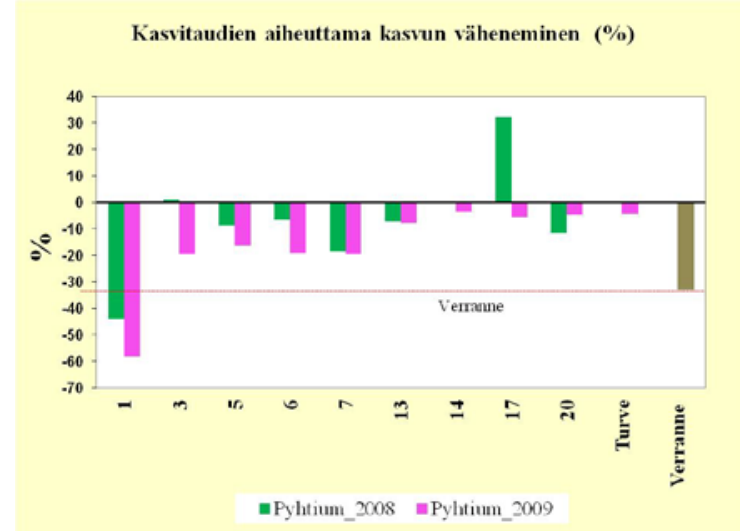

Kuva 1. Samoista raaka-aineista tehtyjen eri kompostierien vaikutus kurkun lakastumistautiin (aiheuttajana Pythium spp.) ja mansikan tyvimätään (aiheuttajana Phytophthora cactorum) ilmaistuna tautisaastutettujen ja saastuttamattomien taimien kuivapainoerona kokeiden lopussa. Verranne on merkitty punaisella viivalla. 


\section{Taudineston ilmeneminen peltomaassa}

Käsittelemättömään pelto- ja puutarhamaahan sekoitettujen kompostien vaikutuksia kurkun lakastumistautiin tutkittiin astiakokeessa. Komposteista kolme (nro 13, 14 ja 20) oli osoittanut taudinestokykyä aikaisemmissa kokeissa. Nyt kuitenkin vain komposti nro 14 ehkäisi kurkun lakastumistautia verranteeseen verrattuna (kuva 2). Nro 13 lisäsi taudin ilmenemistä molemmissa maissa, kun taas komposti nro 20 ehkäisi tautia peltomaassa, mutta lisäsi sitä puutarhamaassa. Komposti nro 1 ei tässä kokeessa vaikuttanut taudin ilmenemiseen, vaikka se oli lisännyt tautia aikaisemmissa kokeissa. Tosin tässä kokeessa Phytophthora-sieni vähensi verranteen kasvuakin vain n. 10 \%, mikä vaikeutti tulosten tulkintaa. Taudille ei siis kokeessa ollut otollisia olosuhteita.

Kenttäkokeessa käytetty komposti nro 14 näytti hiukan lisäävän mansikan tyvimädän oireita lehdissä ja juurakossa (Kuva 3) verrattuna kivennäislannoitukseen ja maanparannusturpeen käyttöön. Tyvimätätauti esiintyi alueella kuitenkin hyvin epätasaisesti, mikä heikensi tulosten luotettavuutta.

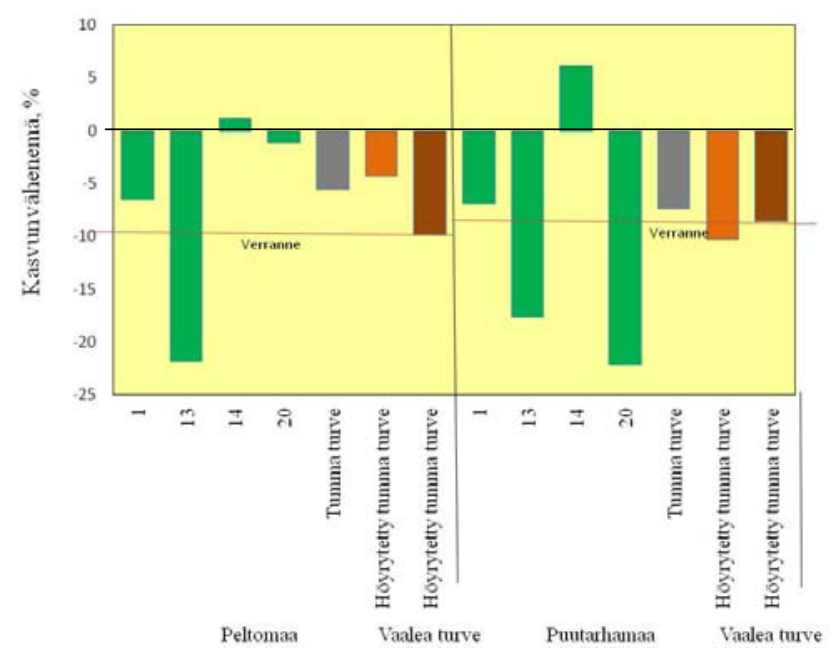

Kuva 2. Neljän kompostin vaikutus kurkun lakastumistautiin (aiheuttajana Pythium spp.) astiakokeessa ilmaistuna tautisaastutettujen ja saastuttamattomien kurkun taimien kuivapainoerona kokeen lopussa. Verranne on merkitty punaisella viivalla. Peruskasvualustana luontainen peltomaa (hkKht, multava) ja puutarhamaa (Kht, multava).

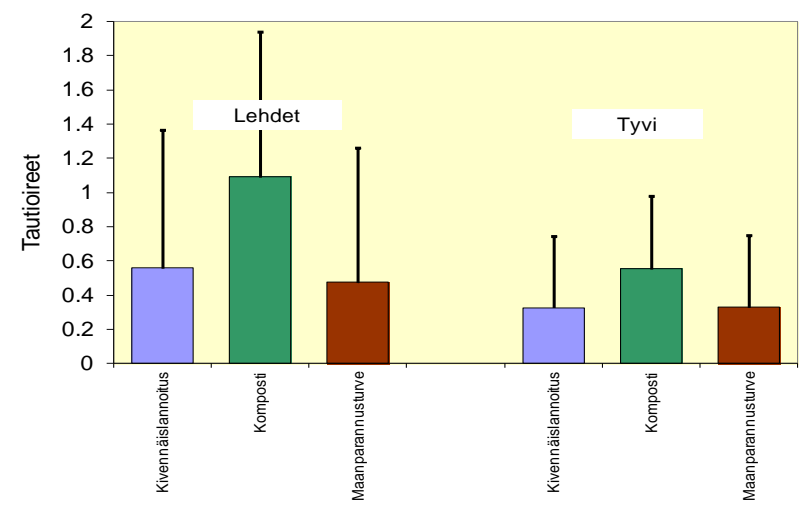

Kuva 3. Kompostin ja maanparannusturpeen vaikutus 'Jonsok' mansikan tyvimätäoireisiin kenttäkokeessa MTT:ssa Piikkiössä vuonna 2010. Aluetta oli keinotekoisesti saastutettu Phytophthora cactorum -sienellä vuonna 2008 (minun muistiinpanoissa on, että saastutus oli tehty 2006). Lehtien lakastumisoireet asteikolla 0-2 (2= täysin lakastunut) ja tyven oireet asteikolla $0,0.1,0.2, \ldots . .1$ (1=hyvin ruskettunut tyvi). 


\section{Tulosten tarkastelu ja yhteenveto}

Olemme alustavasti osoittaneet, että monilla kaupallisesti tuotetuilla suomalaisilla laitoskomposteilla on kyky vähentää mansikan tyvimätää ja kurkun lakastumistautia astiakokeissa. Vaikutus oli erityisen selkeä silloin, kun peruskasvualustana käytettiin höyrytettyä kasvuturvetta. Näissä olosuhteissa kompostimikrobien ei tarvinnut kilpailla kasvualustan muiden mikrobien kanssa. Lisätutkimuksia vaadittaisiin ennen kuin voidaan päätellä missä määrin kompostit voivat ehkäistä kasvitauteja peltoon tai puutarhamaahan levitettynä. Kävi myös ilmi, että taudinesto esiintyi vain kypsissä komposteissa. Tutkimuksessa mukana olleista kompostista muutama ei ollut aivan kypsä. Nämä kompostit eivät vähentäneet tautia, vaan pikemminkin lisäsivät sitä. Kompostin riittävää kypsyyttä pidetäänkin yleensä perusedellytyksenä taudinestokyvylle (Raviv 2009), vaikka poikkeuksia tästä perussäännöstä on myös olemassa (Danon ym. 2007). Taudinestokykyä voidaan sanoa kompostien lisäarvoksi, jonka hyödyntämisestä olisi etua sekä tuottajalle että käyttäjälle. Ilmiön hyödyntämiseen liittyy kuitenkin vielä erittäin paljon ongelmia.

Taatusti taudinestokykyä omaavan kompostin tuottaminen on taudinestoilmiön suurimpia pullonkauloja. Meidänkin tutkimuksessamme komposteilla oli osittain erilainen vaikutus kahteen eri tautiin. Myös laajassa EU-hankkeessa (Termorshuizen ym. 2006) todettiin, että 18 kaupallisesti tuotetun kompostin vaikutus 7 eri kasvitautiin oli varsin vaihteleva. Taudinestokyvyn liittymistä tiettyihin kompostiraaka-aineisiin on myös yleensä ollut vaikea päätellä, koska komposteja tehdään hyvin erilaisista orgaanisista aineista eikä negatiivisia tuloksia aina julkaista (Raviv 2009). Kun meidän tutkimuksessamme lantakompostit eivät juuri osoittaneet taudinestokykyä, niin intialaisten yhteistyökumppaneidemme tutkimuksissa nimenomaan jatropha-jäte + lantakompostit ehkäisivät Fusariumlakastumistautia tomaatilla. Jatrophaa käytetään Intiassa biodieselin valmistuksessa.

Kompostien taudinestokyvyn hallinta vaatii tarkkaa tietoa ilmiön taustalla olevista mikrobiologisista ja/tai muista mekanismeista. Suomalaisessa kompostitutkimuksessa ei ole vielä löytynyt selvää mikrobisto/taudinesto -yhteyttä, vaikka fylogeneettiset analyysit osoittivat, että tiettyä alkuperää olevat kompostit ryhmittyivät yhteen. Vasta kun kompostien taudinestomekanismista on enemmän tietoa, on mahdollista siirtyä tutkimuksissa askel eteenpäin ja mahdollisesti räätälöidä taudinestokomposteja käytettäviksi esim. kasvualustoissa.

\section{Kirjallisuus}

Benhamou, N. \& C. Garand. 2001. Cytological analysis of defense-related mechanisms induced in pea root tissues in response to colonization by nonpathogenic Fusarium oxysporum. Phytopathology 91:730-740.

Chen, W., Hoitink, H. A. J., Schmitthenner, A. F. \& Tuovinen, O. H. 1988. The role of microbial activity in suppression of damping off caused by Pythium ultimum. Phytopathology 78:1447-1450.

Danon, M., Zmora-Nahum, S., Chen, Y. \& Hadar, Y. 2007. Prolonged compost curing reduces suppression of Sclerotium rolfsii. Soil Biolology and Biochemistry 39:1936-1946.

Gorodecki, B. \& Hadar, Y. 1990. Suppression of Rhizoctonia solani and Sclerotium rolfsii disease in container media containing composted separated cattle manure and composted grape marc. Crop Protection 9: 271-274.

Hoitink, H.A.J. \& Boehm, M.J. 1999. Biocontrol within the context of soil microbial communities: a substratedependent phenomenon. Annual Review of Phytopathology 37: 427-446.

Hoitink, H.A.J. \& Poole, H.A. 1976. Composted bark medium for control of soil-borne plant pathogens. American Nurseryman 144: 15, 88-89.

Itävaara, M., Vikman, M. \& Venelampi, O. 1997. Windrow composting of biodegradable packing materials. Compost Science and Utilization 5: 84-92.

Noble, R. \& Coventry, E. 2005. Suppression of soil-borne plant diseases with composts: A review. Biocontrol Science and Technology 15: 3-20.

Oka, Y. and Yermiyahu, U. 2004. Suppressive effects of composts against the root-knot nematode Meloidogyne javanica on tomato. Nematology 4: 891-898.

Raviv, M. 2008. The use of compost in growing media as suppressive agent against soil-borne disease. Acta Horticulturae 779: 39-49.

Raviv, M. 2009. Recent advances in soil-borne disease control using suppressive media. Acta Horticulturae 819: 125-134. 
Schönfeld, J., Gelsomino, A., van Overbeek, L.S., Gorissen, A., Smalla, K. \& van Elsas, J.D. 2003. Effects of compost addition and simulated solarisation on the fate of Ralstonia solanacearum biovar 2 and indigenous bacteria in soil. FEMS Microbiology Ecology 43: 63-74.

Serra-Wittling, C., Houot, S. and Alabouvette, C. 1996. Increased soil suppressiveness to Fusarium wilt of flax after addition of municipal solid waste compost. Soil Biology and Biochemistry 28: 1207-1214.

Termorshuizen, A.J., van Rijn, E., van der Gaag, D.J., Alabouvette, C., Chen, Y., Lagerlöf, J., Malandrakis, A.A., Paplomatas, E.J., Rämert, B., Ryckeboer, J., Steinberg, C. \& Zmora-Nahum, S. 2006. Suppressiveness of 18 composts against 7 pathosystems: variability in pathogen response. Soil Biology \& Biochememistry 38: 3461-3477.

Veeken, A.H.M., Blok, W.J., Curci, F., Coenen, G.C.M., Termorshuizen, A.J. \& Hamelers, H.V. M. 2005. Improving quality of composted biowaste to enhance disease suppressiveness of compost-amended, peat-based potting mixes. Soil Biology \& Biochemistry 37: 2131-2140.

Vestberg, M., Kukkonen, S., Parikka, P., S., Yu, D., Kurola, J., Romantschuk, M. \& Setälä, H. 2010. Laitostuotetuissa komposteissa on taudinestokykyä. Teoksessa: Anneli Hopponen (toim.) Maataloustieteen Päivät 12.-13.1.2010. Suomen maataloustieteellisen seuran tiedote 26: $8 \mathrm{~s}$

Vestberg, M., Kukkonen, S., Rantala, S., Prochazka, P., Tuohimetsä, S., Setälä, H., Romantschuk, M., Kurola, J., Yu, D. \& Parikka, P. 2011. Suppressiveness of Finnish commercial compost against soil borne disease. Acta Horticulturae 891: 59-65.

Yogev, A., Raviv, M., Hadar, Y., Cohen, R. \& Katan, J. 2006. Plant waste-based composts suppressive to diseases caused by pathogenic Fusarium oxysporum. European Journal of Plant Pathology 116: 267-278. 